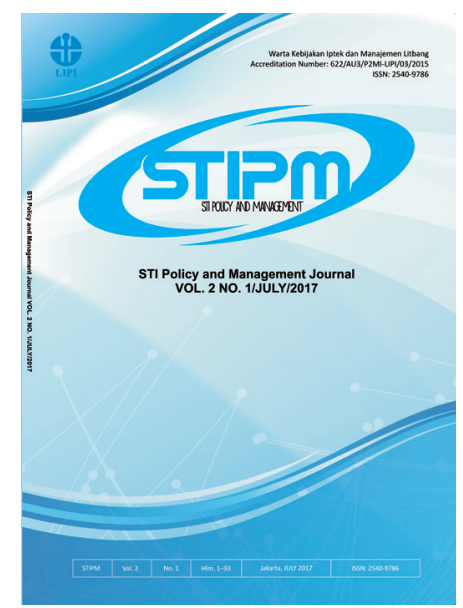

Journal of STI Policy and Management

Publication details, including instructions for authors and subscription information: http://www.stipmjournal.org/

\title{
The Innovative Policy Options for Coastal Fisheries Economic Development: A Case of Kwandang Bay Coastal Ecosystem
}

Noel Taylor-Moore

Australian Volunteer International

Version of record first published: 15 July 2017

To cite this article: Taylor-Moore, N. (2017). The Innovative Policy Options for Coastal Fisheries Economic Development: A Case of Kwandang Bay Coastal Ecosystem. Journal of STI Policy and Management, 2(1), 15-27

To link to this article: http://dx.doi.org/10.14203/STIPM.2017.73

ISSN 2540-9786 (Print); ISSN 2502-5996 (online)

Accreditation Number: 622/AU3/P2MI-LIPI/03/2015

Full terms and conditions of use: https://creativecommons.org/licenses/by-nc-sa/4.0/

You are free to:

- Share : copy and redistribute the material in any medium or format

- Adapt : remix, transform, and build upon the material

- The licensor cannot revoke these freedoms as long as you follow the license terms.

Under the following terms: Attribution - You must give appropriate credit, provide a link to the license, and indicate if changes were made. You may do so in any reasonable manner, but not in any way that suggests the licensor endorses you or your use.

$\$$ NonCommercial - You may not use the material for commercial purposes.

(2) ShareAlike - If you remix, transform, or build upon the material, you must distribute your contributions under the same license as the original.

No additional restrictions - You may not apply legal terms or technological measures that legally restrict others from doing anything the license permits.

Notices:

- You do not have to comply with the license for elements of the material in the public domain or where your use is permitted by an applicable exception or limitation.

- No warranties are given. The license may not give you all of the permissions necessary for your intended use. For example, other rights such as publicity, privacy, or moral rights may limit how you use the material.

- If you copy the dataset merely to extract the uncopyrightable data elements would not need permission to do so. However, if you republish the full dataset or using the copyrightable data layers require a permission from PAPPIPTEK-LIPI. 


\title{
JOURNAL OF SCIENCE, TECHNOLOGY AND INNOVATION POLICY AND MANAGEMENT (STIPM JOURNAL), Volume 02, Number 01, July 2017
}

\author{
FOREWORD by EDITOR-in-CHIEF
}

We are very pleased to inform readers that Journal of Science, Technology and Innovation Policy and Management (STIPM Journal) Vol. 2, No. 1, July 2017 is now ready for public reading.

The STIPM Journal is an online research journal managed by the Center for Science and Technology Development Studies at the Indonesian Institute of Sciences (PAPPIPTEK-LIPI). As a peer-reviewed journal, the STIPM Journal provides free access to research thoughts, innovation, and original discoveries mostly aimed at scholars.

In this edition, the STIPM Journal contains six articles dealing with science, technology and innovation policy and management written by scholars from Japan, Australia, and Indonesia.

The first article is entitled "Innovation Process of Natural Resource-based Firms in Four ASEAN Economies: A SEM Approach" by Masatsugu Tsuji, Hiroki Idota, Yasushi Ueki, and Teruyuki Bunno. Using a structural equation model (SEM), this paper discusses the innovation process in natural resourcebased industries in Vietnam, Indonesia, the Philippines, and Thailand in comparison to other assembling and processing industries by focusing how factors affect product as well as process innovation.

The second article is written by Noel Taylor-Moore, entitled "The Innovative Policy Options for Coastal Fisheries Economic Development: A Case of Kwandang Bay Coastal Ecosystem”. This article uses a policy innovation framework in the context of STI inputs and a multi-level perspective (MLP), selects a potential site in which a fisheries economic development hub would be implemented, and performs a SWOT analysis of the selected site as a hub.

Erman Aminullah, Trina Fizzanty, Karlina Sari, Rizka Rahmaida, and Qinan M. B. Soesanto present the third article, "Interactive Learning for Upgrading and Growth: Case of Indonesian Fishery Firms." This article discusses an interactive learning model for upgrading and growth in Indonesian fishery firms using the case of fish processing and aquaculture (shrimp). The model suggests that the dynamics of upgrading and growth through interactive learning will be able to continue in a stable manner as constraints from limiting elements are eased through: combating illegal fishing; encouraging interaction with universities; shifting to higher added-value products; increasing institutional support for global trading; preventing shrimp diseases; and providing infrastructure, business facilities, and regulation information.

The fourth article, entitled "Developing the Marine and Fisheries Industry in Pangandaran using a Bioecoregion-based Technopark Framework", is written by Atikah Nurhayati and Agus H. Purnomo. This article discusses how to establish a marine and fisheries technopark in Pangandaran. By using gap and SWOT analysis, it was found that particular recommendations for improvement should be made, 
the existing bioecoregional environment and development variables in Pangandaran would support the development of a marine and fisheries technopark.

The fifth article, entitled "Development of National Technology Audit Policy", is presented by Subiyanto. This article discusses the concept of a national technology auditing policy, particularly with regard to infrastructure requirements, and with emphasis on technical regulation effectiveness and implementation tool readiness. This article discusses setting a policy agenda by discussing the governance aspect of national technology auditing.

The final article is written by Anugerah Yuka Asmara and Toshio Mitsufuji with the title "Photovoltaic Development from the New Order Era to the Reform Era in Indonesia: From a Technological Innovation System Perspective”. This article discusses the phenomena of PV development between the New Order era and the Reform era using a technological innovation system (TIS) approach. This paper concludes that PV projects and technology could not be developed en masse without intervention from the government in both the New Order era and the Reform era.

We also would like to thank the authors, editors, and reviewers who have worked very hard for this edition. We hope that all the articles featured in this edition proves useful to the reader.

Jakarta, 16 July 2017

Editor-in-Chief 



\section{JOURNAL OF STI POLICY AND MANAGEMENT}

Volume 2, Number 1, July 2017

\section{LIST OF CONTENTS}

Innovation Process of Natural Resource-based Firms in Four ASEAN Economies: A SEM Approach

Masatsugu Tsuji, Hiroki Idota, Yasushi Ueki, and Teruyuki Bunno

The Innovative Policy Options for Coastal Fisheries Economic Development: A Case of Kwandang

Bay Coastal Ecosystem

Noel Taylor-Moore

Interactive Learning for Upgrading and Growth: Case of Indonesian Fishery Firms

Erman Aminullah, Trina Fizzanty, Karlina Sari, Rizka Rahmaida, and Qinan M.B. Soesanto

Developing the Marine and Fisheries Industry in Pangandaran using a Bioecoregion-based Technopark Framework

Atikah Nurhayati and Agus Heri Purnomo

Development of National Technology Audit Policy

Subiyanto.

Photovoltaic Development from the New Order Era to the Reform Era in Indonesia:

From a Technological Innovation System Perspective

Anugerah Yuka Asmara and Toshio Mitsufuji. 


\title{
if STI POLICY AND MANAGEMENT

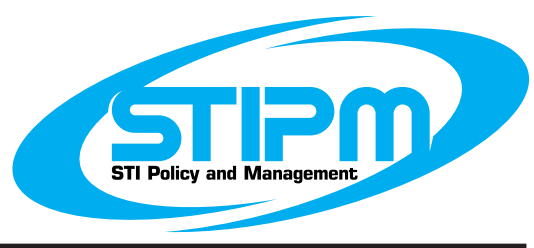

\section{The Innovative Policy Options for Coastal Fisheries Economic Development: A Case of Kwandang Bay Coastal Ecosystem}

\author{
Noel Taylor-Moore \\ Australian Volunteer International
}

\begin{tabular}{|c|c|}
\hline ARTICLE INFO & ABSTRACT \\
\hline $\begin{array}{l}\text { Article History: } \\
\text { Received : 08 December } 2016 \\
\text { Revised : } 23 \text { May } 2017 \\
\text { Accepted : 05 July } 2017 \\
\text { Available online : } 15 \text { July } 2017\end{array}$ & $\begin{array}{l}\text { Socio-environmental problems, such as climate change, pollution } \\
\text { and habitat destruction, present serious challenges for fisheries } \\
\text { economic development. The integration of interventions or } \\
\text { investments within a coastal marine ecosystem, a defined spatial } \\
\text { area, is considered important in the economic development of }\end{array}$ \\
\hline $\begin{array}{l}\text { Keywords: } \\
\text { Policy innovation } \\
\text { Coastal marine ecosystem } \\
\text { Fisheries economic development hub } \\
\text { Value chains } \\
\text { Multi-level perspective (MLP) }\end{array}$ & $\begin{array}{l}\text { food security, and conservation. The coastal marine ecosystem } \\
\text { is the provider of products and services to the local economy } \\
\text { adjacent to the ecosystem where the benefit flows, within that } \\
\text { area, are interconnected. The roles of science, technology and } \\
\text { innovation (STI) are an integral part of these multi-dimensional } \\
\text { interventions. Hence, there is a need for an integrated approach } \\
\text { for these interventions by government and/or through donor- } \\
\text { funded projects to enhance economic development of coastal } \\
\text { communities. The policy framework proposed is therefore an STI } \\
\text { perspective of the links between these intervention and investment } \\
\text { options, based on a 'fisheries economic development hub' and } \\
\text { discussed using the multi-level perspective (MLP). The policy } \\
\text { innovation proposal suggests an implementation strategy of a pilot } \\
\text { project and analyzes the selection and implications of a potential } \\
\text { Indonesian site for the application of a Hub. The paper considers } \\
\text { a policy innovation framework in the context of STI inputs and } \\
\text { a multi-level perspective (MLP), selects a potential site in which } \\
\text { fisheries economic development hub would be implemented, and } \\
\text { performs a SWOT analysis of the selected site as a hub. }\end{array}$ \\
\hline
\end{tabular}

C2017 PAPPIPTEK-LIPI All rights reserved

\section{INTRODUCTION}

The development of coastal communities, reliant on coastal marine resources, has been supported by interventions and investments by both the Indonesian government and donor-funded programs.

\footnotetext{
* Corresponding Author.

E-mail: ntaylormoore@hotmail.com
}

Within these programs, the policy framework, in most cases, relies on a set of individual projects seemingly linked by the common aim towards the usual outcomes of food security, livelihoods and conservation of an ecosystem.

However, many of these projects are carried out in isolation from each other and spatially sepa- 
rated. For example, the projects or programs for interventions relating to i) climate change impacts on local communities based on climate change adaptation measures or ii) interventions related to effective management for sustainable fisheries; or iii) effective management of marine management areas for improving coral reef diversity, can individually occur without determining the joint impacts that all three interventions might have on food security, livelihoods, and conservation of coastal natural resources, in the same spatial area. And from a multidimensional perspective, unfortunately, the policy framework maybe integrated based on the projects of institutional strengthening, capacity building and gender actions.

As the development of coastal fisheriesbased communities is multidimensional in nature, a relevant development policy framework should reflect those dimensions. For example, the integration of the multidimensional program interventions or investments, within a designated coastal marine ecosystem, is considered important for the economic development of coastal communities. The resulting impacts indicated by value-adding, along the related value chains and the socio-cultural changes related to those changes. This paper takes the socioeconomic and conservation dimensions as the key indicators of the fisheries development outcomes. Science, technology, and innovation (STI) are key inputs for these interventions and investments. But how do these key inputs relate to a policy innovation for coastal fisheries economic development?

To support the analysis, a multi-level perspective (MLP) approach (Geels, 2012; Nykvist $\&$ Whitmarsh, 2008) is used to illustrate coastal fisheries economic development as a systemic transition involving multidimensional interactions at three levels, those being landscape, the exogenous context of the economic, ecological and cultural conditions; socio-technical regime, the fisheries sector's dominant actors, institutions, practices and shared assumptions; and niche innovations of individual technologies and grassroots movements. Interactions between the systems underpinning fisheries economic development include scientific knowledge, R\&D, technology improvements, innovation of policy and related legislation, market mechanisms, cultural norms and roles, fisheries and seafood infrastructure, coastal marine ecosystems, conservation planning, and community structures. The connectivity of science, technology, and innovation is a central factor within the integration of policy interventions.

The coastal marine ecosystem is "a community of plants, animals, and smaller organisms that live, feed, reproduce, and interact in the same area or location" (WWF, 2012) that provides products and services to the local economy, where the benefit flows within the coastal marine ecosystem area are interconnected.

The proposed policy framework (TaylorMoore, 2014), is therefore an economic perspective that links these intervention and investment options based on a policy innovation called the 'fisheries economic development Hub' (Hub). The paper considers a policy innovation framework in the context of STI inputs and a multi-level perspective (MLP), selects a potential site for implementing the fisheries economic development Hub, and performs a SWOT analysis of the selected site as a Hub.

\section{ANALYTICAL FRAMEWORK}

Fisheries economic development within a coastal marine ecosystem, for example, may be based on five keys development and growth intervention options for STI inputs. Taylor-Moore (2014, p.13) suggests options such as i) infrastructure interventions (e.g. fish landing centers, wharfs and service facilities, service roads, service supply technologies, waste management); ii) supply chain interventions (e.g. cold storage, ice production, processing, product innovation, export certification, logistics, business management, and entrepreneurship innovations); iii) management and regulatory interventions (e.g. Ecosystem Approach to Fisheries Management (EAFM)fisheries research, Marine Managed Areas (MMA)-conservation and no-go zone research, and climate change adaptation measures (CCA)vulnerable assessments); iv) ecosystem stressor interventions (coastal resource management, local planning, rehabilitation), and v) institutional strengthening and capacity building interventions 
(e.g. technology investment in government agencies, communities, and stakeholders). Each of these groups of interventions requires different investment strategies involving a range of STI inputs.

However, interventions need to be supported by an enabling environment (e.g. fisheries sector agencies policy, planning and financial support, certification, health and hygiene regulations, administration of the hub area, logistic operations, financial institutions, private sector and community engagement, $R \& D$, extension services, reigning institutions, and HR). These interventions are based on lessons learned in countries such as Sri Lanka (Diffey, 2012; Taylor-Moore, 2016).

The proposed policy innovation for achieving sustainable fisheries development outcomes lies within a multidimensional context, including the key economic, social and conservation dimensions and as potential areas for STI inputs (Table 1).

The policy innovation of the fisheries economic development Hub, based on coastal marine ecosystem services, is defined for the purposes of the paper as "a geographical area, related to a defined coastal marine ecosystem, where policy innovation provide linkages for improving ecosystem biodiversity, sustainable fisheries and better food security/livelihoods through the application of integrated interventions and investments" (Taylor-Moore, 2014, p. 8). In this context, fisheries economic development includes i) a defined ecosystem; ii) coastal marine resources, capture fisheries, aquaculture farming, ecotourism; iii) fisheries management systems, ecosystem management systems, climate change adaptation management system; and iv) the fisheries infrastructure and fish supply chains.
Ecosystem Services (WWF, 2012) are benefit flows derived from a coastal marine ecosystem. These are i) products directly supplied from the ecosystem, such as fish protein and or services such as ecotourism; ii) benefits of natural processes, such as tidal flows to support cage mariculture; iii) benefits of basic ecological functions and processes that support flora and fauna; and iv) cultural services gained from human relationships with the ecosystem.

Key policy development and growth intervention options, linked to STI inputs, are also shown in Figure 1.

The Asian Development Bank (ADB, 2014, p. 70) provides a model of "how a supply chain management approach facilitates job creation, income increases, and wealth creation through prioritizing and sequencing interventions to determine and overcome weaknesses in the supply chain".

The policy innovation, providing pathways to achieving the economic development outcomes, through an integrated approach, can be illustrated as the input-output-outcome perspectives of the linkages and resulting value chains of products and services derived from the selected coastal marine ecosystem.

Tasrif (2014, p. 101) makes the case for the importance of technology in an economic system as the unseen linkage of the factors of production and service provision as "the technology element is embedded in both production factors; capital and labor".

Fig. 2 is a complex, but clear representation of what the policy innovation framework entails in relation to the need for and the impacts of science, technology, and innovation.

Table 1.

Key Sustainable Fisheries Economic Development Dimensions as Areas for Science, Technology, and Innovation Inputs

\begin{tabular}{llll}
\hline \multicolumn{2}{c}{ Key sustainable fisheries economic development dimensions for STI inputs } \\
\hline Economic & \multicolumn{1}{c}{ Social } & Conservation \\
\hline - Improved livelihoods from alternative activities & $\bullet$ & Amenity improvement & $\bullet$ Habitat rehabilitation \\
- Appropriate infrastructure & $\bullet$ & Social cohesion & $\bullet$ Improved ecosystem biodiversity \\
- Consolidated fisheries value chains & $\bullet$ & Educational opportunities $\bullet$ & $\bullet$ Climate change adaptations \\
- Product management & $\bullet$ & Waste disposal and hygiene & \\
\hline
\end{tabular}




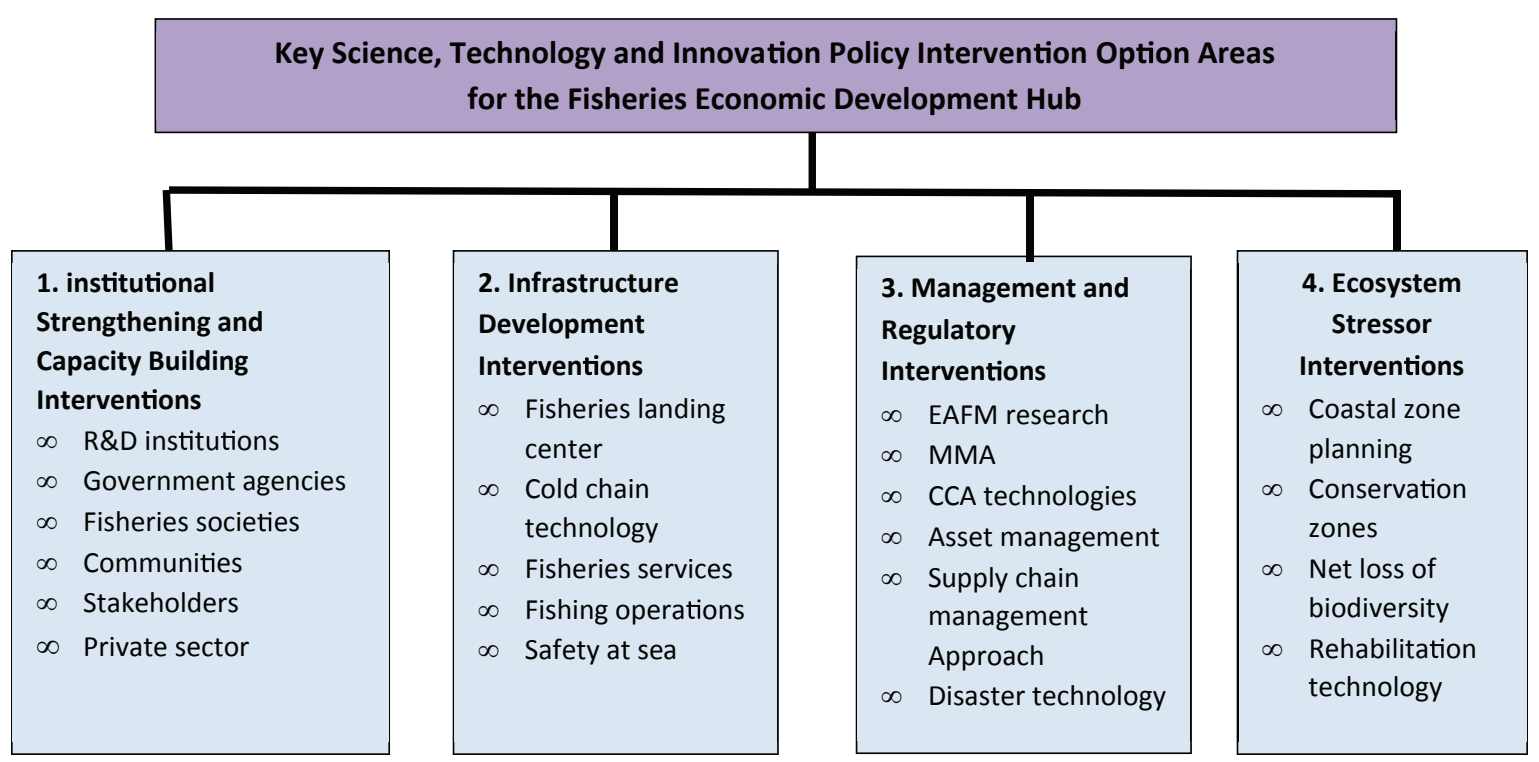

Figure 1. Potential Policy STI Intervention Options for the Fisheries Economic Development Hub

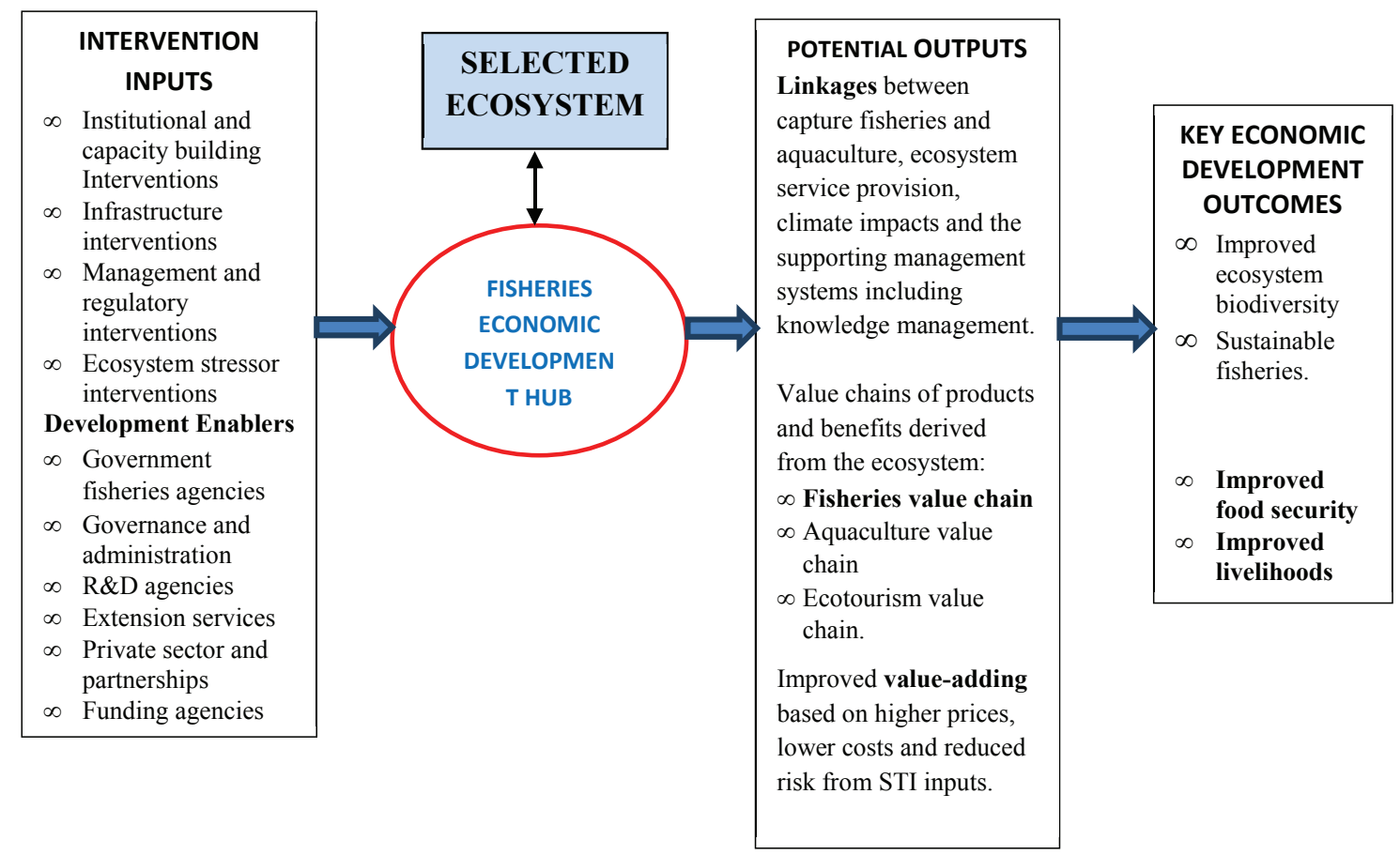

Figure 2. Fisheries Economic Development Hub as an Input-Output-Outcome System

The hub is the geographical region within which the integrated interventions lead to three key outputs; linkages between all economic processes related to ecosystem services, three important value chains, and improved value adding. The outcomes of potential improvements in food security and livelihoods are based on the hub outcomes of improved ecosystem biodiversity and sustainable fisheries.
Coastal fisheries economic development, being a significant factor to increased food security and livelihood outcomes, within the Hub, is usually based around fisheries landing centers and the fisheries value chain of capture fisheries and aquaculture (Fig. 3).

Each of the interventions/investments and development enablers (Fig. 3) has a range of potential STI inputs to support the policy innovation. For example: 
1) Management and regulatory interventions (fish aging technology, fish biology, R\&D for GPS technology, ecosystem research, climate change vulnerability research, impact analysis of closed areas);

2) Capture fishing operations (fish-finding technology, eco-friendly fishing gear, GPS applications, safer boats, FADs, etc.);

3) Fish supply (post-harvest technologies, logistics);

4) Fish landing centers (waste and hygiene technologies, software packages for data collection and analysis, business training, infrastructure planning); and

5) Fisheries value chains (processing innovations cold storage technologies, logistics, export technologies, packaging technologies, business planning).

Finally, the key questions of the policy innovation development and implementation are as follows.

\section{Policy Area}

1) What problems and issues are clearly understood and defined based on evidence?

2) What questions arise from that understanding?

3) What are the critical issues that need a solution?

4) What potential options are available based on evidence?

5) What technical issues, within the hub and for specific STI issues, relating to the policy options, been clearly defined?

6) What are the objectives, outputs, and outcomes of the policy framework?

7) What strategies are selected to achieve the chosen policy options?

8) What is the implementation and communication processes underpinning the policy?

Implementation Strategy Area

1) What district should be chosen to implement the policy?

2) Does the district have a coastal marine ecosystem that can be the basis for establishing a fisheries economic development hub (Table $1)$ ?

3) What are the appropriate, workable interventions and/or investment options (including STI inputs) needed within the hub to address the findings of (iii)?

4) What priorities, objectives, actions and outcomes have been agreed to for the interventions within the hub?

5) What intervention and investment options are analyzed and have been agreed to?

6) What economic development enablers are present or available for the hub?

7) What indicators, for M\&E purposes, reflect the changes within the hub and the agreed outcomes?

8) How can the policy innovation be implemented and managed within the chosen site?

A log-frame should be drawn up integrating the above areas.

The paper will not provide answers to all these questions, but suggests an innovative policy framework for the structure of a pilot project and the implication for STI inputs.

\section{METHODOLOGY}

A case study of the potential implementation of the policy innovation was undertaken in the selected province with a specific district coastal marine ecosystem. For the selected site of the hub to be successful, certain criteria-such as the characteristics of the ecosystem, key actives within the hub, and the enabling environmentwere selected (Table 2).

The selection of a coastal marine ecosystem was based on a key outcome of food security. An indicator chosen from this outcome was the $\mathrm{kg}$ of fish protein produced by each household within a province sourced through either capture fisheries and/or aquaculture farming. This simple fish protein data can be used as a means to select the province where a fisheries economic development hub could be established, based on the following key data: i) production of capture fisheries product (ton/year) per household; ii) production of aquaculture product (ton/year) per household; 


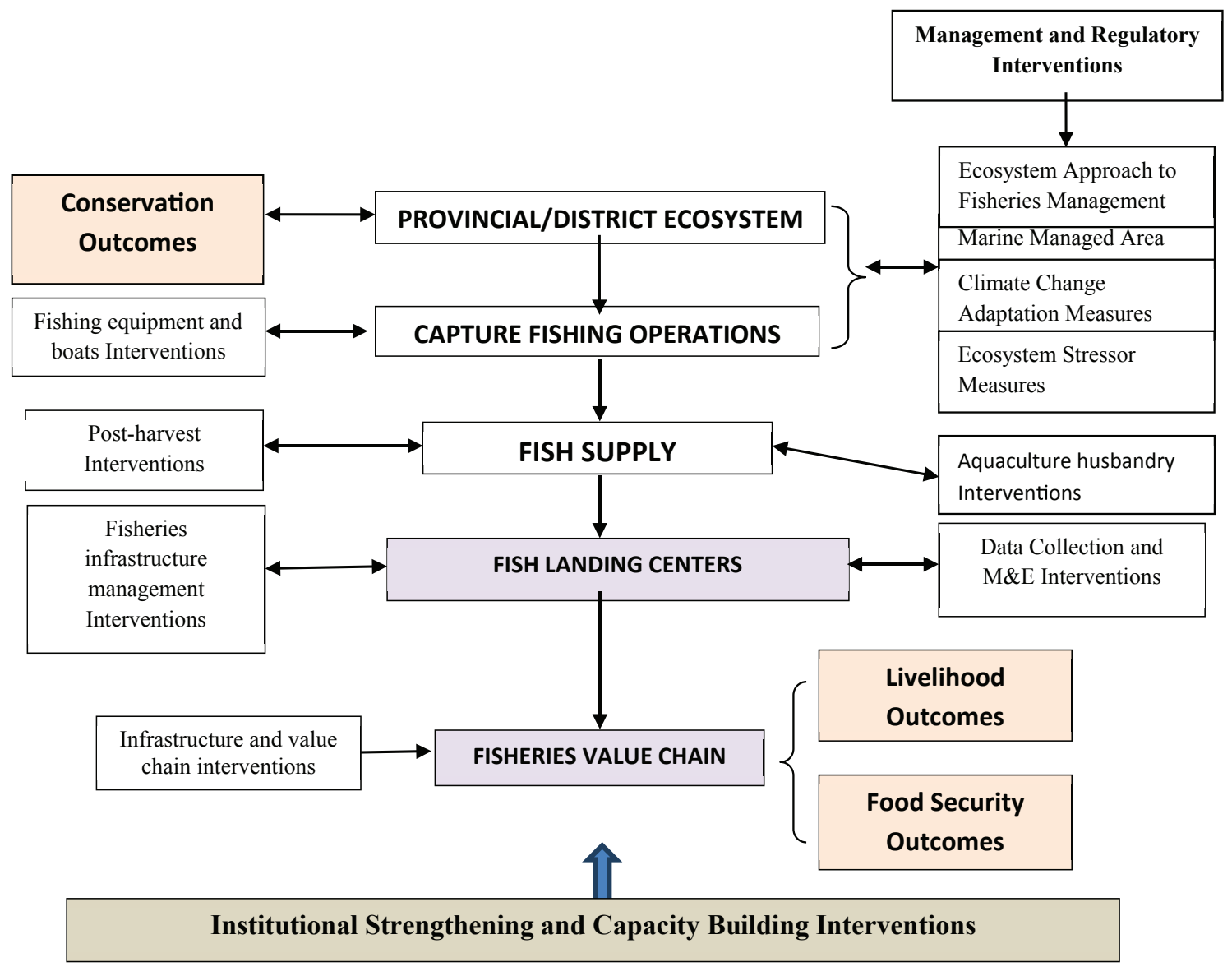

Figure 3. Policy Intervention Linkages of Coastal Fisheries Within an Ecosystem-Based Economic Development Hub

Table 2.

Key Criteria and Related Success Factors Considered for the Selection of a Coastal Marine Ecosystem for the Implementation of a Proposed Fisheries Economic Development Hub

\begin{tabular}{|c|c|}
\hline Site selection criteria & Key Success Factors \\
\hline Characteristics of ecosystem & $\begin{array}{l}\text { 1. Sited within a priority seascape } \\
\text { 2. A defined ecosystem within the seascape } \\
\text { 3. Area of ecosystem } \\
\text { 4. Biodiversity of the ecosystem } \\
\text { 5. MPA in place or proposed } \\
\text { 6. Size of MPAs } \\
\text { 7. Climate change impacts }\end{array}$ \\
\hline Key activities within the hub & $\begin{array}{l}\text { 1. Key fisheries; } \\
\text { 2. Diversified fisher participation; } \\
\text { 3. Fish landing centre and services; } \\
\text { 4. Fisheries value chain; } \\
\text { 5. Aquaculture development; } \\
\text { 6. Tourism development. }\end{array}$ \\
\hline Enabling environment & $\begin{array}{l}\text { 1. Strategic planning [e.g. Minapolitan] } \\
\text { 2. Agency participation } \\
\text { 3. Administration support } \\
\text { 4. Financial institution support } \\
\text { 5. Logistics } \\
\text { 6. Private sector support } \\
\text { 7. Research availability } \\
\text { 8. Extension support } \\
\text { 9. Training support available } \\
\text { 10. Community participation } \\
\text { 11. Synergy with other programs }\end{array}$ \\
\hline
\end{tabular}


iii) number of households undertaking capture fisheries; and iv) the number of households undertaking aquaculture.

Using these data, findings from 15 provinces were mapped as a relationship between levels of household protein production and by focus of the source of the product (i.e. capture fisheries or aquaculture).

The criteria were based on the Indonesian production data of the Coral Triangle Initiative (CTI) as follows.

1) Proportion of total households with a focus on capture fisheries and/or aquaculture, and

2) Household protein production, compared to the CTI mean household protein production (ton/year).

Based on this relationship, each province was graded, as illustrated in Table 3.

The related fisheries value chain within the chosen site (ecosystem) was also considered in terms of two policy innovation outcomes: private and public development intervention support and the benefits that flow through the value chain. The implications of the interconnectedness of STI inputs of the policy interventions are described through a multi-level perspective, based on a SWOT analysis of the hub site.

\section{RESULTS AND DISCUSSION}

\section{A. Selection of Hub Site}

The analysis of 15 potential sites for a fisheries economic development hub, shows great variation in the relationship between protein production per household and the source of protein (capture fisheries and/or aquaculture) across provinces (Table 4) and their respective geographical location (Figure 4).

Potential sites were narrowed down to Group $\mathrm{B}$, based on the higher level of both protein production per household and the focus on capture fisheries. This relationship would provide a greater range of the intervention options, suggested in the policy framework, as the economic activity within the hub is likely to be broader and deeper and more easily monitored and evaluated (M\&E).

For example, Gorontalo Province, allocated to Group B, had above mean protein production per household and a higher focus on production from capture fisheries rather than aquaculture

Table 3.

Grading Matrix of Criteria of Province Marine Production Focus and Mean Protein Production Per Household

\begin{tabular}{ccc}
\hline $\begin{array}{c}\text { Production focus of household } \\
\text { activity }\end{array}$ & \begin{tabular}{c} 
CTI mean level of fish protein production per household (ton/year) \\
\cline { 2 - 3 } $\begin{array}{c}\text { per household (ton/year) } \\
\text { capture fisheries }\end{array}$
\end{tabular} & $\begin{array}{c}\text { Higher than mean level of production per } \\
\text { household (ton/year) }\end{array}$ \\
\hline $\begin{array}{c}\text { Households with high focus in } \\
\text { capture fisheries }\end{array}$ & Group A & Group B \\
\hline $\begin{array}{c}\text { Households with a lower focus on } \\
\text { caph D }\end{array}$ & Group C \\
\hline
\end{tabular}

Table 4.

Results of Province Grouping Based on the Grading Criteria Matrix (Table 2).

\begin{tabular}{|c|c|c|}
\hline \multirow[b]{2}{*}{ Production focus of household activity } & \multicolumn{2}{|c|}{ CTI mean level of fish protein production per household (ton/year) } \\
\hline & $\begin{array}{l}\text { Lower level of production per } \\
\text { household (ton/year) }\end{array}$ & $\begin{array}{l}\text { Higher level of production per household } \\
\text { (ton/year) }\end{array}$ \\
\hline $\begin{array}{l}\text { Households with high focus in capture } \\
\text { fisheries }\end{array}$ & $\begin{array}{l}\text { Group A } \\
\text { North Sulawesi } \\
\text { West Papua } \\
\text { Papua } \\
\text { East Java }\end{array}$ & $\begin{array}{l}\text { Group B } \\
\text { Cental Sulawesi } \\
\text { Gorontalo } \\
\text { Maluku }\end{array}$ \\
\hline $\begin{array}{l}\text { Households with low focus in capture } \\
\text { fisheries (more aquaculture focus) }\end{array}$ & $\begin{array}{l}\text { Group D } \\
\text { East Kalimantan } \\
\text { Central Kalimantan } \\
\text { South Kalimantan } \\
\text { West Sulawesi }\end{array}$ & $\begin{array}{l}\text { Group C } \\
\text { East Nusa Tenggara } \\
\text { South Sulawesi } \\
\text { Southeast Sulawesi } \\
\text { North Maluku }\end{array}$ \\
\hline
\end{tabular}




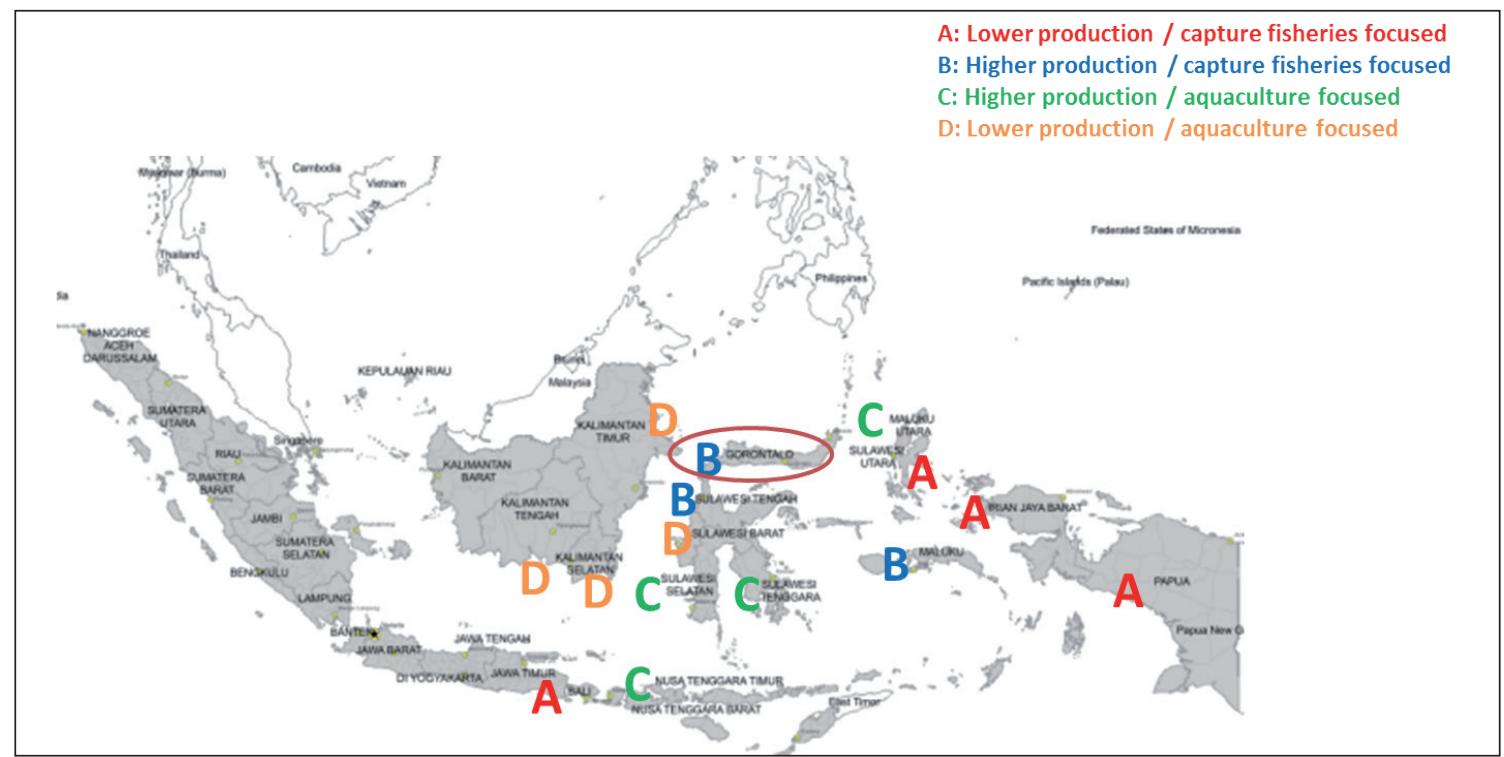

Figure 4. Map of Table 3 Findings

farming. The district of Kwandang of Gorontalo Province was selected as the hub site based on the characteristics applicable to an integrated approach to fisheries economic development (Table 2) and a site visit.

Whereas other choices, for example, could have been Papua Province (Group A) which had a high proportion of households in capture fisheries, but a low level of production per household; Central Kalimantan Province (Group D) had both a lower level of focus on capture fisheries and a low level of production per households; whilst South Sulawesi Province (Group C) had a high level of production per household with a lower focus on capture fisheries. However, Groups A, C, D may have less ability to absorb the policy innovation.

\section{B. Kwandang Bay ecosystem in Gorontalo Province}

The ecosystem chosen was Kwandang Bay, which spans about 30,000 ha within the district of Kwandang (Fig. 5). Kwandang District has a $200 \mathrm{~km}$ coastline and a population of 104,000. The ecosystem is diverse with sea grass meadows and coral reefs around small islands, lying in an open bay (some $20 \mathrm{~nm}$ across the opening) into the Sulawesi Sea. It also contains fisheries such as tuna, demersal and small pelagics taken by a variety of catching gears such as purse seine, fixed nets that move throughout the bay, bagans catching anchovies and sardines, line fishing by both traditional fishers, and outboard boats (Table 5a). Fish cages are also found in the bay. There is no obvious zoning plan. The fisheries/aquaculture sector in Gorontalo and its relative growth are shifting from capture fisheries to aquaculture, from 2009 to 2012 of $646 \%$ and with an overall growth of $100 \%$ (refer to Table $5 b$ ).

There are two fish landing centres within the hub area, the larger one managed centrally and the smaller by the district, both of which need upgrading. Key issues discussed were ice machines and fluctuating demands, wharf space, sanitation/ hygiene, post-harvest technologies and training of fishers and businessmen using purse seine operations. For governance and logistic support for this potential hub site, there is only one government agency, the district fisheries department, which is also responsible for the small landing site situated just outside the bay. The need for capacity building was stressed at the provincial, district, fishers, and business meetings. There is an EAFM pilot project under an $\mathrm{ADB}$ project that is also a key synergy.

The Gorontalo Province Fisheries has a sound development plan for aquaculture and there are floating cages scattered around Kwandang Bay, in the deeper and cleaner waters. This is a key component of the livelihood development 


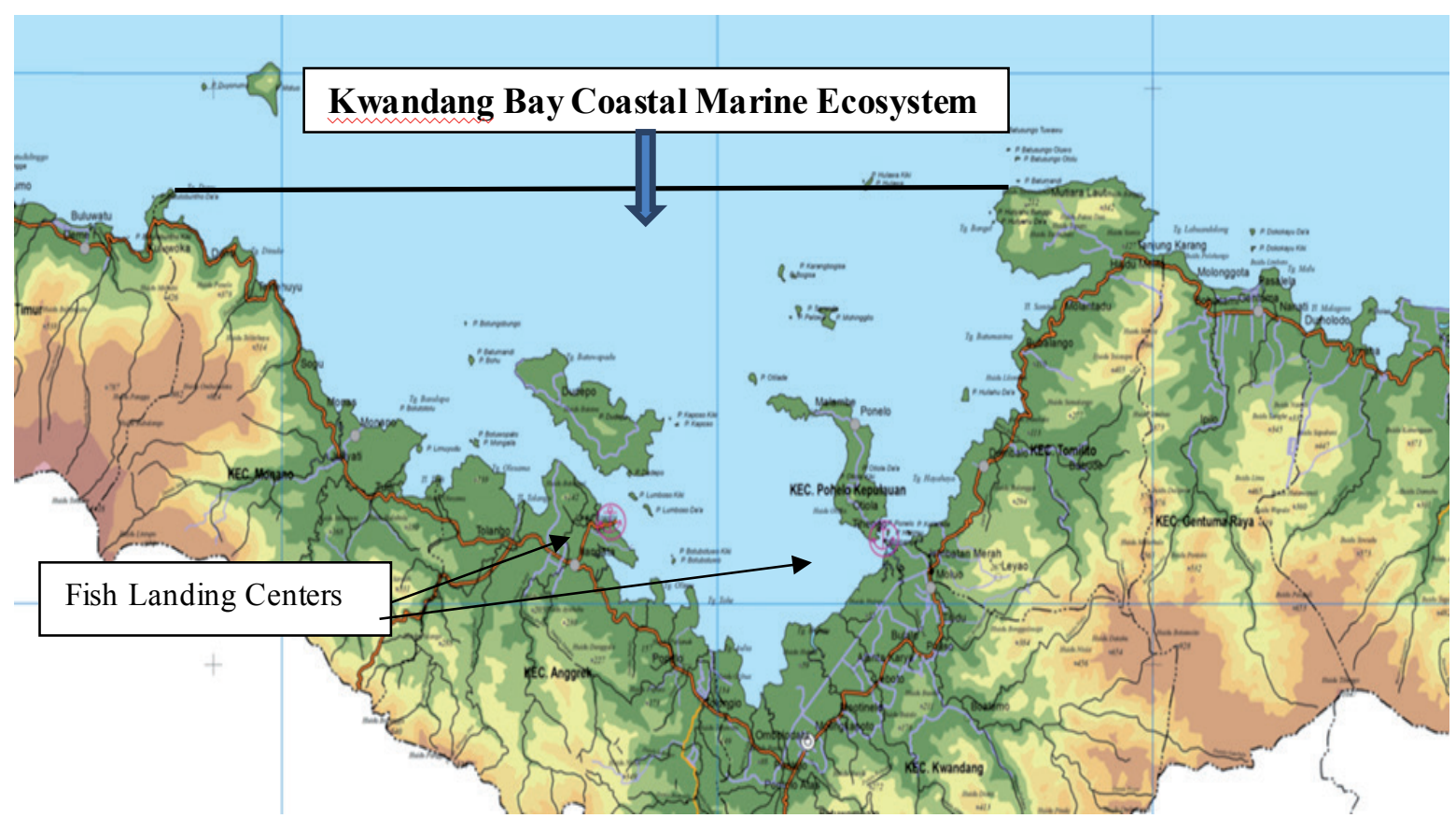

Figure 5. Kwandang Bay Coastal Marine Ecosystem Potential Hub Site

\section{Table 5a.}

Types of Fishing Boats Operating in Gorontalo Province

\begin{tabular}{lcc}
\hline Type of fishing boats & Number & Percentage \\
\hline Non-powered boat & 1,679 & 20 \\
\hline Outboard motorboat & 6,545 & 77 \\
\hline Inboard motorboat & 231 & 3 \\
\hline TOTAL & 8,455 & 100 \\
\hline
\end{tabular}

\section{Table 5 b.}

Details of Fisheries/Aquaculture Sector of Gorontalo Province

\begin{tabular}{lcccc}
\hline \multicolumn{1}{c}{ Marine Sector } & Households & Production 2009 $[\mathrm{t}]$ & Production 2012 [t] & Change \\
\hline Capture fisheries & 7,779 & 4,186 & 3,567 & $-15 \%$ \\
\hline Marine Culture & 2542 & 48,283 & 95,482 & $+98 \%$ \\
\hline Brackish water & 944 & 2,290 & 3,716 & $+62 \%$ \\
\hline Cage & 156 & 68 & 136 & \\
\hline Floating Cage & 782 & 1,097 & 8,189 & $+646 \%$ \\
\hline TOTAL & 12,203 & 55,924 & 111,450 & $+99 \%$ \\
\hline
\end{tabular}

Source: Gorontalo Provincial data for both tables. Specific data of fisheries activities is not available at district level.

of the province. The central government has the Minapolitan program and the district has a 2013 fisheries-based Minapolitan planning document. The Gorontalo Province also has a climate change strategy that is applicable to Kwandang Bay.

To illustrate further the role of potential interventions by both the private and public sectors, a more detailed fisheries value chain is presented in Table 6. The private and public sector intervention support is an area of potential STI inputs, including the measurement of the benefit flows of the policy innovation. STI inputs suggested as needed for the Kwandang Bay fisheries value chain development include the following.

1) Private sector: fishing gear $R \& D$, GPS fishing operations technology, fisheries management science, post-harvest technology, waste management technology, cold chain technology, marketing and product innovation, funded innovation projects, and micro-financing technologies 
Table 6.

Private and public support for policy-based benefit flows within the fisheries value chain of Kwandang Bay coastal ecosystem and STI implications/actions

\begin{tabular}{|c|c|c|c|c|c|}
\hline $\begin{array}{l}\text { Fisheries value chain } \\
\text { components }\end{array}$ & $\begin{array}{l}\text { Private sector } \\
\text { policy support }\end{array}$ & & $\begin{array}{c}\text { Potential } \\
\text { benefit flows }\end{array}$ & \multicolumn{2}{|r|}{$\begin{array}{l}\text { Government sector policy } \\
\text { support }\end{array}$} \\
\hline $\begin{array}{c}\text { Fish operation suppliers } \\
\text { (e.g., vessel, gears, } \\
\text { electricity) }\end{array}$ & $\begin{array}{l}\text { 1) Sustainable fishing } \\
\text { equipment at an } \\
\text { affordable cost to fishers } \\
\text { 2) R\&D sharing } \\
\text { 3) Knowledge sharing } \\
\text { 4) Energy management } \\
\text { 5) Boat building }\end{array}$ & 1) & $\begin{array}{l}\text { New volume growth } \\
\text { with long-term contract } \\
\text { with fisheries economic } \\
\text { development hub } \\
\text { Sustainable fishing } \\
\text { practices used and fish } \\
\text { stocks improving } \\
\text { Safety-at-sea }\end{array}$ & 2) & $\begin{array}{l}\text { Co-financing for trained } \\
\text { fishermen to buy } \\
\text { sustainable fishing } \\
\text { equipment } \\
\text { R\&D for gear } \\
\text { improvement } \\
\text { Boat- building program }\end{array}$ \\
\hline $\begin{array}{l}\text { Fish catch (e.g., tuna, small } \\
\text { pelagics, and demersal } \\
\text { fish ) }\end{array}$ & $\begin{array}{l}\text { 1) Training to learn } \\
\text { sustainable fishing skills } \\
\text { 2) Provision of new } \\
\text { equipment to replace } \\
\text { inefficient and destructive } \\
\text { gears } \\
\text { 3) GPS technologies } \\
\text { 4) Catch database } \\
\text { development } \\
\text { 5) New fisheries }\end{array}$ & 3) & $\begin{array}{l}\text { Price improvement with } \\
\text { better quality } \\
\text { Management plans } \\
\text { leading to cohesive fisher } \\
\text { collaboration } \\
\text { Long-term risk mitigation } \\
\text { from overfishing } \\
\text { Fish handling } \\
\text { improvements }\end{array}$ & $\begin{array}{l}\text { 3) } \\
\text { 4) }\end{array}$ & $\begin{array}{l}\text { Training fishermen to } \\
\text { lead to sustainable } \\
\text { fishing practices. } \\
\text { Fish management plans } \\
\text { and certification } \\
\text { Community engagement } \\
\text { Catch record } \\
\text { technologies }\end{array}$ \\
\hline $\begin{array}{l}\text { Seafood } p \\
\text { potential } c a\end{array}$ & $\begin{array}{l}\text { 1) Value adding the lower } \\
\text { volume growth from fish } \\
\text { catch } \\
\text { 2) R\&D \& knowledge sharing } \\
\text { 3) Sanitation and post } \\
\text { harvest technologies } \\
\text { 4) R\&D budgets } \\
\text { 5) Export driven action }\end{array}$ & 1) & $\begin{array}{l}\text { assurance from } \\
\text { tion } \\
\text { d employment }\end{array}$ & 1) & -develop more \\
\hline Seafood wholesale & $\begin{array}{l}\text { 1) Lower volume growth } \\
\text { from fish catch } \\
\text { 2) R\&D \& knowledge sharing } \\
\text { 3) Ice use in markets }\end{array}$ & 1) & $\begin{array}{l}\text { Quality assurance } \\
\text { Reduced health problems }\end{array}$ & 2) & $\begin{array}{l}\text { business- friendly } \\
\text { policies } \\
\text { Stable tax system for the } \\
\text { seafood sector }\end{array}$ \\
\hline $\begin{array}{l}\text { Seafood retailing, } \\
\text { restaurants, and } \\
\text { e-commerce }\end{array}$ & $\begin{array}{l}\text { 1) Lower volume growth } \\
\text { from fish catch } \\
\text { 2) R\&D \& knowledge sharing } \\
\text { 3) Product branding }\end{array}$ & 1) & $\begin{array}{l}\text { Price improvement with } \\
\text { better quality } \\
\text { Branded product with } \\
\text { certification } \\
\text { Quality improvement } \\
\end{array}$ & $\begin{array}{l}4) \\
5)\end{array}$ & $\begin{array}{l}\text { Policy and strategic } \\
\text { planning } \\
\text { Certification for exports } \\
\text { R\&D research on } \\
\text { processing and } \\
\text { marketing }\end{array}$ \\
\hline $\begin{array}{l}\text { Logistics and storage (e.g., } \\
\text { freezing) }\end{array}$ & $\begin{array}{l}\text { 1) Invest initial fixed capital } \\
\text { for underserved logistics } \\
\text { needs } \\
\text { 2) Ice machines at fishing } \\
\text { centers } \\
\text { 3) Purpose built trucks for } \\
\text { transporting product }\end{array}$ & & $\begin{array}{l}\text { Price premium to offer a } \\
\text { fresher seafood delivery } \\
\text { or storage solution }\end{array}$ & 6) & $\begin{array}{l}\text { Developing } \\
\text { entrepreneurship } \\
\text { capabilities } \\
\text { Health and hygiene } \\
\text { certification }\end{array}$ \\
\hline $\begin{array}{l}\text { Advertising and marketing } \\
\text { support }\end{array}$ & $\begin{array}{l}\text { 1) Brand sustainable fishing } \\
\text { products } \\
\text { 2) Ocean-to-plate marketing } \\
\text { 3) 'Fresh is best' } \\
\text { 4) Clean-green products }\end{array}$ & 1) & $\begin{array}{l}\text { Better public image } \\
\text { High- end sales }\end{array}$ & & \\
\hline Financial access support & $\begin{array}{l}\text { Microfinance for } \\
\text { equipment purchase with } \\
\text { high credit risk exposure }\end{array}$ & & $\begin{array}{l}\text { New market access of } \\
\text { new customer pool with } \\
\text { growth potential }\end{array}$ & & $\begin{array}{l}\text { Co-develop financing } \\
\text { program for trained } \\
\text { fishermen }\end{array}$ \\
\hline
\end{tabular}

Note: Nested within the above potential interventions (Table 6) are the interconnectedness of STI inputs along the value chain which is connected to the Gorontalo provincial and Indonesian national value chains so these potential STI inputs within the Kwandang Bay Hub have flow-on effects to the larger economic system. 
2) Public sector: R\&D institutions supporting local community fisheries, policy innovation for local area management of fisheries, training of fishers in the use of fishing operation technologies, R\&D institutions providing fisheries science to support fish management plans, and business management training for use of technologies relevant to local communities.

It should be noted that the level of sophistication of the STI inputs relates to the development level required and the developmental capabilities of the actors within the hub.

\section{Policy implications for Kwandang Bay coastal marine ecosystem as a development hub}

During the site visit meetings with fishermen, business representatives, processors, and government officials, data were collected related to the policy innovation. The SWOT analysis (Table 7) summarizes the findings of the potential of the fisheries economic development hub policy innovation being piloted within the Kwandang Bay coastal marine ecosystem.

Aminullah, Fizzanty, Indraprahasta, \& Asmara (2016) examined the technological capabilities and entrepreneurship of Indonesian processing companies, with conclusion supporting the found weaknesses and potential opportunities of value-adding of fish within the hub. follows.

Key findings of the SWOT analysis are as

1) Kwandang Bay, being a beautiful bay opening into the Sulawesi Sea with deep and clean marine waters, is essential for the supply of a clean-green ecosystem seafood products and services for tourism;

2) The shift towards higher demand for mariculture products is supported by the required Kwandang District government's aquaculture development strategy;

3) It is a diverse fishery that lacks in management plans or development strategies;

4) Fish landing centers are inadequate, requiring upgrading with regard to sanitation and hygiene issues;

5) There is no zoning within the bay and therefore there is a need for marine management areas to be developed and implemented, supported by ecotourism and other beneficiaries of the bay's ecosystem services;

6) The tuna fishery, being based on the juvenile skipjack tuna, may well have overfishing problems within the waters of the Sulawesi Sea and other skipjack fisheries;

7) There is potential for community participatory processes to support investment and interventions; and

\section{Table 7.}

SWOT Analysis of Kwandang Bay Coastal Marine Ecosystem as a Potential Hub Site

\begin{tabular}{ll}
\multicolumn{1}{c}{ Strengths } & Weaknesses \\
1) Diverse ecosystem/open bay & 1) Energy management \\
2) One administration & 2) Limited cold chain \\
3) Minapolitan & 3) Inadequate fish landing center sanitation/hygiene \\
4) 2 functioning fish landing sites & 4) Limited private investment \\
5) Aquaculture development plan & 5) Limited government funding \\
6) 2013 development plan & 6) Limited HR capacity development \\
7) Gorontalo Province climate change strategy & 7) Lack of fisheries plans \\
8) Small and large pelagic fishery & 8) No zoning within the bay \\
9) Development projects in the area & 9) Overfishing of key species \\
\hline \multicolumn{1}{c}{ Oportunities } & \\
1) Reduced overfishing via alternative livelihoods & 1) Tuna fishery based on juvenile skipjack tuna \\
2) Ecotourism & 2) Linkages too complex to manage \\
3) Clean-green products & 3) Private sector not willing to invest \\
4) Processing of selected species & 4) Government investment unlikely \\
5) Capacity building using Manado training center & 5) Limited community engagement in development \\
6) Post-harvest/new products & 6) Marine management areas poorly funded and managed. \\
7) EAFM/CCA/MMA linkage & 7) Business management not implemented \\
8) Posible seaweed industry development & 8) Lock-in mechanisms hamper changes \\
\hline
\end{tabular}


Table 8.

Potential Transitions of Coastal Fisheries Economic Development through Policy Innovation Interventions within the Kwandang Hub

\begin{tabular}{|c|c|c|}
\hline $\begin{array}{c}\text { Potential MLP Level } \\
\text { Changes }\end{array}$ & & Key Potential Policy Innovation Interventions \\
\hline $\begin{array}{l}\text { Socio-technical } \\
\text { landscape (changes } \\
\text { impacting on the } \\
\text { fisheries economic } \\
\text { development within the } \\
\text { hub) }\end{array}$ & $\begin{array}{l}\text { 2) } \\
\text { 3) } \\
\text { 4) } \\
\text { 5) }\end{array}$ & $\begin{array}{l}\text { Emerging climate change impacts on the coastal ecosystem internalised within } \\
\text { Indonesian society. } \\
\text { Political resource reallocation to fisheries development under new government policies } \\
\text { Export-driven planning } \\
\text { World's best economic development practices implemented } \\
\text { Changing societal beliefs through socialization }\end{array}$ \\
\hline $\begin{array}{c}\text { Socio-technical regime } \\
\text { (transitions of fisheries } \\
\text { economic development } \\
\text { within the hub) }\end{array}$ & $\begin{array}{l}\text { 1) } \\
\text { 2) } \\
\text { 3) } \\
\text { 4) } \\
\text { 5) } \\
\text { 6) } \\
\text { 7) } \\
\text { 8) } \\
\text { 9) } \\
\text { 10) }\end{array}$ & $\begin{array}{l}\text { Fisheries within the hub under agreed management plans } \\
\text { Aquaculture within the hub under agreed management plans } \\
\text { Community/stakeholder participatory processes agreed to } \\
\text { R\&D application at the community levy } \\
\text { Fisheries and community infrastructure funded } \\
\text { Rules, norms etc. at collective level socialized and agreed to } \\
\text { Compliance frameworks enhanced and adhered to } \\
\text { Regulation and legislation based on negations of stakeholders } \\
\text { Livelihood alternatives developed to reduce fishing effort } \\
\text { Lock-in mechanisms reduced by private and public investment }\end{array}$ \\
\hline $\begin{array}{l}\text { Niche innovations } \\
\text { impacting on the } \\
\text { socio-technical regime } \\
\text { (application of new } \\
\text { technology and } \\
\text { processes on fisheries } \\
\text { economic development) }\end{array}$ & $\begin{array}{l}\text { 2) } \\
3) \\
4) \\
5) \\
6)\end{array}$ & $\begin{array}{l}\text { Policy of integrated intervention from vision of new approaches to community fisheries } \\
\text { development } \\
\text { M\&E technologies developed } \\
\text { New science of ecosystem analysis developed } \\
\text { Compliance technologies developed } \\
\text { Multi-dimensional learning approaches } \\
\text { Knowledge management methodologies }\end{array}$ \\
\hline
\end{tabular}

8) There is limited private and public investment available to develop the required infrastructure and human resource capabilities to manage fisheries-related activities within the hub.

Considering the findings of the SWOT analysis, the implications for policy innovations within the Kwandang Hub are summarized through an MLP framework (Table 8). The improvements within the hub are considered as transitions within the regime-in other words, the fisheries sector and its related activities within the Kwandang Hub have undergone changes as a result of the potential STI supported interventions of the policy innovation

\section{CONCLUSION}

The policy framework proposed is an example of a multi-dimensional perspective of the connections between potential intervention and investment options, supported by STI inputs, based on the concept of a fisheries economic development hub.
The policy innovation proposal was considered by selecting a potential pilot site for the implementation strategy: a coastal marine ecosystem. An analysis of 15 potential provinces was based on the relationship between fish protein produced by village households and the source of that protein (a capture fishing and/or aquaculture farming focus). Results showed great variation in the relationship between protein production per household and the source of protein across the 15 provinces. Three provinces had the characteristics of a higher level of protein production and a higher level focus on capture fisheries (Central Sulawesi, Gorontalo, and Maluku). Following a site visit to the Gorontalo Province for background information and discussion with government officials, industry, and local fishers, Kwandang Bay was selected as the potential site.

A SWOT analysis of the Kwandang Bay ecosystem, as a potential hub for interventions and investments in the fisheries sector, showed that overall, currently, fisheries economic development within the Kwandang Hub is essentially weak but has the potential for improved food 
security and livelihoods through an integrated intervention policy, implemented and supported by STI inputs, within the Hub.

Findings from the SWOT analysis of the Kwandang Bay ecosystem as a hub were discussed using a multi-level perspective (MLP), showing that the transitions of fisheries economic development, stimulated by the policy innovation, can be described in terms of the interconnectedness of the changes at the landscape, regime and niche level, and the potential impacts flowing from STI inputs.

\section{REFERENCES}

Asian Development Bank (ADB). (2014). Myanmar: Unlocking the potential country - Diagnostic study. Manilla: ADB

Aminullah, E., Fizzanty, T., Indraprahasta, G. S., \& Asmara, I. J. (2016). Technological capability upgrading and entrepreneurship: Case study of selected Indonesian fish processing companies. STI Policy and Management Journal, 1(1), 41-57. (http://dx.doi.org/10.14203/ STIPM.2016.34)

CTI Interim-Regional Secretariat. (2013). Summary report: Coral triangle initiative on coral reefs, fisheries and food security. 2nd Regional Priorities workshop, Manado, Indonesia.

Diffey, S. (2012). Developing fish landing centers. Experiences and lessons from Sri Lanka. Geneva: UNFAO.

Geels, F. W. (2012). A socio-technical analysis of lowcarbon transitions: introducing the multi-level perspective into transport studies. Journal of Transport Geography, 24, 471-482. (https:// doi.org/10.1016/j.jtrangeo.2012.01.021).
Nykvist, B., \& Whitmarsh, L. (2008). A multi-level analysis of sustainable mobility transitions: Niche development in the UK and Sweden. Technological forecasting and social change, 75(9), 1373-1387. (https://doi.org/10.1016/j. techfore.2008.05.006).

Tasrif, M. (2014). The role of technology in Indonesian economy: A system-dynamic model. Journal of $S \& T$ Policy \& $R \& D$ Management, 12(2), 89-114.

Taylor-Moore, N. G. (2014). Sustainable financing, projects and concepts: Application of the fisheries economic development hub concept to a sustainable finance-based pilot project. TA-7813 REG. Manilla: Asian Development Bank.

Taylor-Moore, N. G. (2016a). Introduction of a villagebased freshwater fisheries co-management approach for (Myanmar) open waters: Policy advisory notes. FAO project GCP/MYA/010/ ITA, Myanmar.

Taylor-Moore, N. G., Romalli, G., Lwin, M. M. \& Oo, A. H. (2016b). Implementation of a villagebased freshwater fisheries co-management approach for (Myanmar) open waters: Field Guide. FAO project GCP/MYA/010/ITA, Myanmar.

World Fish Center. (2013). Community-based marine resource management in Solomon Islands: A facilitator's guide.

WWF. (2012). Report: Ecological footprint and investment in natural capital in Asia and the Pacific. 